\title{
Effects of viscosity and fermentability of dietary fibre on nutrient digestibility and digesta characteristics in ileal-cannulated grower pigs
}

\author{
Seema Hooda, Barbara U. Metzler-Zebelit, Thavaratnam Vasanthan and Ruurd T. Zijlstra* \\ Department of Agricultural, Food and Nutritional Science, University of Alberta, Edmonton, AB, Canada T6G 2P5
}

(Received 16 July 2010 - Revised 27 January 2011 - Accepted 31 January 2011 - First published online 4 May 2011)

\begin{abstract}
Relative contributions of two functional properties, viscosity and fermentability of dietary fibre, on apparent ileal digestibility (AID), apparent total tract digestibility (ATTD), digesta passage rate, $\mathrm{N}$ retention and SCFA concentration have not been established. Thus, eight ileal-cannulated pigs randomised in a double $4 \times 4$ Latin square were fed four diets based on maize starch and casein supplemented with $5 \%$ of actual fibre in a $2 \times 2$ factorial arrangement: low-fermentable, low-viscous cellulose (CEL); low-fermentable, high-viscous carboxymethylcellulose (CMC); high-fermentable, low-viscous oat $\beta$-glucan (LBG); high-fermentable, high-viscous oat $\beta$-glucan (HBG). Viscosity and fermentability interacted to affect $(P<0 \cdot 001)$ digesta viscosity and AID and ATTD of nutrients. These properties tended to interact to affect $(P<0 \cdot 10)$ digesta passage rate and butyrate. Pigs fed the CMC diet had the lowest $(P<0 \cdot 05)$ digesta passage rate and the highest $(P<0 \cdot 001)$ AID of energy, crude protein and DM, and ATTD of energy and DM. Post-ileal DM digestibility was highest $(P<0.001)$ for pigs fed the CEL and HBG diets. Post-ileal DM digestibility had a negative, curvilinear relationship with the AID of energy and crude protein $\left(R^{2} 0.85\right.$ and 0.72 , respectively; $\left.P<0.001\right)$. Digesta viscosity had a less strong relationship with the AID of energy and crude protein $\left(R^{2} 0.45\right.$ and $0 \cdot 36$, respectively; $\left.P<0 \cdot 001\right)$. In conclusion, high-viscous, low-fermentable dietary fibre increases the proportion of a diet that is digested in the small intestine by reducing digesta passage rate.
\end{abstract}

\section{Key words: Dietary fibre: Fermentability: Pigs: Viscosity}

Dietary fibre is an important component of dietary ingredients but is not digested by porcine digestive enzymes. Dietary fibre may be fermented, mostly in the large intestine, and may reduce the digestibility of other macronutrients ${ }^{(1)}$. The physiological effects of dietary fibre are attributable to two functional properties, viscosity and fermentability ${ }^{(2)}$. Viscous fibre binds water, increases digesta viscosity, modifies digesta passage rate and thereby reduces nutrient digestibility in the small intestine $e^{(3,4)}$. Fermentable fibre contributes a major part of the non-digested nutrients that pass into the large intestine and are fermented by microbial populations, thereby producing SCFA ${ }^{(5)}$.

The effects of types of dietary fibre on nutrient digestibility have been linked to structural characteristics and solubility of fibre ${ }^{(4,6,7)}$. However, the role and specific contributions of viscosity and fermentability are largely unknown. Moreover, most studies investigating the role of fibre are based on feeding fibre-rich ingredients containing fibre as part of intact plant cell wall; therefore, specific effects of functional properties or structural effects cannot be differentiated ${ }^{(8)}$. Thus, the concept of feeding purified fibre fractions with semi-purified diets was adopted to study specific contributions of viscosity and fermentability and their possible interactions. However, results with isolated fibre ingredients should be extrapolated carefully to natural fibre feed ingredients.

The hypothesis of the present study was that viscosity and fermentability of fibre independently affect digesta characteristics and nutrient digestibility in pigs. The objectives were to understand the independent and interactive effects of the two functional properties of dietary fibre in semi-purified diets on nutrient digestibility, digesta characteristics, passage rate, SCFA concentration and $\mathrm{N}$ retention in ileal-cannulated grower pigs.

\section{Materials and methods}

\section{Animals and diets}

The animal protocol was approved by the Animal Care Committee of the University of Alberta and followed the guidelines

\footnotetext{
Abbreviations: AA, amino acids; ADG, average daily gain; AID, apparent ileal digestibility; ATTD, apparent total tract digestibility; CEL, low-fermentable, low-viscous cellulose; CMC, low-fermentable, high-viscous carboxymethylcellulose; HBG, high-fermentable, high-viscous oat $\beta$-glucan; LBG, highfermentable, low-viscous oat $\beta$-glucan; PC, principal component.
}

*Corresponding author: Dr R. T. Zijlstra, fax +1 780492 4265, email ruurd.zijlstra@ualberta.ca

†Present address: Research Unit Nutritional Physiology 'Oskar Kellner', Leibniz-Institute for Farm Animal Biology, 18196 Dummerstorf, Germany. 
established by the Canadian Council on Animal Care ${ }^{(9)}$. The animal experiment was conducted at the Swine Research and Technology Centre at the University of Alberta (Edmonton, AB, Canada).

A total of eight crossbred barrows (initial body weight, 20$25 \mathrm{~kg}$; Duroc $\times$ Large White/Landrace; Hypor, Inc., Regina, SK, Canada) were moved 1 week before surgery into individual metabolism pens $(1.2 \times 1.2 \mathrm{~m})$. Each pen was equipped with a single-space feeder and a low-pressure bowl drinker. Pigs were surgically modified with a T-cannula at the distal ileum. At $10 \mathrm{~d}$ post-surgery, eight pigs were randomly assigned to one of the four experimental diets according to a double $4 \times 4$ Latin square design. The daily feed allowance was adjusted to $3 \times$ maintenance of energy $(3 \times 460 \cdot 2 \mathrm{~kJ} \mathrm{DE} / \mathrm{kg}$ body weight $\left.{ }^{0.75}\right)^{(10)}$ and was fed as mash in two equal meals at 08.00 and 16.00 hours with free access to water.

The four semi-purified experimental diets were based on maize starch, casein and rapeseed oil (Table 1). Diets contained 5\% of actual dietary fibre corrected for impurities, from four sources differing in viscosity and fermentability: low-fermentable, low-viscous cellulose (CEL, TIC Pretested ${ }^{\circledR}$ TICACEL 100 cellulose powder; TIC Gums, Inc., White Marsh, MD, USA); low-fermentable, high-viscous carboxymethylcellulose (CMC, TIC Pretested ${ }^{\circledR}$ CMC 6000 fine powder; TIC Gums, Inc.); high-fermentable, low-viscous oat $\beta$-glucan (LBG, Oat Vantage ${ }^{\circledR}$; GTC Nutrition, Golden, CO, USA); high-fermentable, high-viscous oat $\beta$-glucan (HBG, Viscofiber $^{\circledR}$; Cevena Bioproducts, Edmonton, AB, Canada). The LBG diet had a lower molecular weight than the HBG diet (81000 v. $1100000 \mathrm{Da}$ ). High- and low-viscous dietary fibre were selected based on in vitro viscosity measurements ${ }^{(11)}$. High- and low-fermentable dietary fibre were selected based on in vitro gas production measurements ${ }^{(12)}$. Diets were fortified with vitamin and mineral to meet or exceed the nutrient requirements of pigs ${ }^{(10)}$. $\mathrm{TiO}_{2}$ was included in the diets as an indigestible marker.

\section{Experimental procedure}

Each $17 \mathrm{~d}$ experimental period consisted of a $10 \mathrm{~d}$ of acclimatisation to diets, followed by a $3 \mathrm{~d}$ collection of faeces and urine samples and a $4 \mathrm{~d}$ collection of ileal digesta. Faeces were collected from 08.00 to 16.00 hours after attaching bags to rings glued around the anus ${ }^{(13)}$. Urine was collected in buckets containing $25 \mathrm{ml}$ of concentrated $\mathrm{H}_{2} \mathrm{SO}_{4}$ for $24 \mathrm{~h}$, and weighed and pooled for $3 \mathrm{~d}$. For digestibility measurements, Ileal digesta were collected from 08.00 to 16.00 hours into plastic bags (10 $\mathrm{cm}$ in length and $4 \mathrm{~cm}$ in diameter) containing $8 \mathrm{ml}$ of $10 \%(\mathrm{v} / \mathrm{v})$ formic acid to minimise bacterial fermentation. Every third bag of digesta was collected without

Table 1. Ingredient composition of the experimental diets containing four fibre sources (as-fed basis)

\begin{tabular}{|c|c|c|c|c|}
\hline \multirow[b]{2}{*}{ Ingredients $(\mathrm{g} / \mathrm{kg})$} & \multicolumn{2}{|c|}{ Low-fermentable } & \multicolumn{2}{|c|}{ High-fermentable } \\
\hline & $\begin{array}{c}\text { Low-viscous } \\
\text { CEL }\end{array}$ & $\begin{array}{l}\text { High-viscous } \\
\text { CMC }\end{array}$ & $\begin{array}{c}\text { Low-viscous } \\
\text { LBG }\end{array}$ & $\begin{array}{c}\text { High-viscous } \\
\text { HBG }\end{array}$ \\
\hline Maize starch* & $729 \cdot 0$ & 718.5 & 688.5 & $674 \cdot 6$ \\
\hline Calcium caseinate & $160 \cdot 0$ & $160 \cdot 0$ & $160 \cdot 0$ & $160 \cdot 0$ \\
\hline Cellulose & $52 \cdot 0$ & - & - & - \\
\hline CMC§ & - & 62.5 & - & - \\
\hline LBG\| & - & - & 89.5 & - \\
\hline HBG & - & - & - & $92 \cdot 5$ \\
\hline Dicalcium phosphate & $12 \cdot 0$ & $12 \cdot 0$ & $12 \cdot 0$ & $12 \cdot 0$ \\
\hline Celite $^{\star \star}$ & $10 \cdot 0$ & $10 \cdot 0$ & $10 \cdot 0$ & $10 \cdot 0$ \\
\hline Rapeseed oil & $10 \cdot 0$ & $10 \cdot 0$ & $10 \cdot 0$ & $10 \cdot 0$ \\
\hline Limestone & 9.0 & $9 \cdot 0$ & $9 \cdot 0$ & $9 \cdot 0$ \\
\hline Mineral premix†† & $5 \cdot 0$ & $5 \cdot 0$ & $5 \cdot 0$ & $5 \cdot 0$ \\
\hline Vitamin premixł‡ & $5 \cdot 0$ & $5 \cdot 0$ & $5 \cdot 0$ & $5 \cdot 0$ \\
\hline Salt & $5 \cdot 0$ & $5 \cdot 0$ & $5 \cdot 0$ & $5 \cdot 0$ \\
\hline $\mathrm{TiO}_{2}$ & 3.0 & $3 \cdot 0$ & 3.0 & 3.0 \\
\hline
\end{tabular}

CEL, low-fermentable, low-viscous cellulose; CMC, low-fermentable, high-viscous carboxymethylcellulose; HBG, high-fermentable, high-viscous oat $\beta$-glucan; LBG, high-fermentable, low-viscous oat $\beta$-glucan.

*Melojel (National Starch and Chemical Company, Bridgewater, NJ, USA).

† Spray-dried calcium caseinate (American Casein Company, Burlington, NJ, USA)

‡TIC Pretested ${ }^{\circledR}$ TICACEL 100 cellulose powder (TIC Gums, Inc.); $100 \mathrm{~g}$ contains $99 \mathrm{~g}$ of insoluble dietary fibre, $28 \mathrm{mg} \mathrm{Na}$ and $3 \mathrm{mg} \mathrm{Ca}$.

§TIC Pretested ${ }^{\circledR}$ CMC 6000 fine powder (TIC Gums, Inc., White Marsh, MD, USA); $100 \mathrm{~g}$ contains $80 \mathrm{~g}$ of soluble dietary fibre, $7943 \mathrm{mg} \mathrm{Na}, 9 \mathrm{mg} \mathrm{Ca}$ and $19 \mathrm{mg} \mathrm{K}$.

\|OatVantage ${ }^{\mathrm{TM}}$ oat bran concentrate (GTC Nutrition, Golden, CO, USA); $100 \mathrm{~g}$ contains $54 \mathrm{~g} \beta$-glucan, $5 \mathrm{~g}$ of moisture, $12 \mathrm{~g}$ of protein, $2 \mathrm{~g}$ of total fat, $5 \mathrm{~g}$ of ash, $71 \mathrm{~g}$ of total carbohydrates, $54 \mathrm{~g}$ of total dietary fibre, $16 \mathrm{~g}$ of starch, $350 \mathrm{mg} \mathrm{Ca}, 140 \mathrm{mg} \mathrm{Mg}$ and $88 \mathrm{mg} \mathrm{P.}$

I Viscofibre ${ }^{\circledR}$ oat $\beta$-glucan concentrate (Cevena Bioproducts, Edmonton, AB, Canada); $100 \mathrm{~g}$ contains $45 \mathrm{~g} \beta$-glucan, $7 \mathrm{~g}$ of moisture, $80.1 \mathrm{~g}$ of total carbohydrates, $70.6 \mathrm{~g}$ of total dietary fibre $(57.3 \mathrm{~g}$ (soluble) and $13.4 \mathrm{~g}$ (insoluble)), $45 \mathrm{~g}$ 3-glucan, $7.1 \mathrm{~g}$ of starch, $4.7 \mathrm{~g}$ of protein, $4 \mathrm{~g}$ of lipids and $4.1 \mathrm{~g}$ of ash.

** Acid-insoluble ash (Celite Corporation, Lompoc, CA, USA).

††Provided per kg of diet: $\mathrm{Zn}, 100 \mathrm{mg}$ as $\mathrm{ZnSO}_{4} ; \mathrm{Fe}, 80 \mathrm{mg}$ as $\mathrm{FeSO}_{4} ; \mathrm{Cu}, 50 \mathrm{mg}$ as $\mathrm{CuSO}_{4} ; \mathrm{Mn}, 25 \mathrm{mg}$ as $\mathrm{MnSO}_{4}$; I, $0.5 \mathrm{mg}$ as $\mathrm{Ca}\left(\mathrm{IO}_{3}\right)_{2} ; \mathrm{Se}, 0.1 \mathrm{mg}$ as $\mathrm{Na}_{2} \mathrm{SeO}_{3}$.

㧊 Provided per kg of diet: retinol, $2.5 \mathrm{mg}$; cholecalciferol, $20.6 \mu \mathrm{g}$; $\alpha$-tocopherol, $2.7 \mu \mathrm{g}$; niacin, $35 \mathrm{mg}$; D-pantothenic acid, $15 \mathrm{mg}$; riboflavin, $5 \mathrm{mg}$; menadione, $4 \mathrm{mg}$; folic acid, $2 \mathrm{mg}$; thiamin, $1 \mathrm{mg}$; D-biotin, $0.2 \mathrm{mg}$; cyanocobalamin, $0.025 \mathrm{mg}$. 
formic acid for SCFA analyses. The bags were removed when filled approximately $70 \%$ with digesta and immediately frozen at $-20^{\circ} \mathrm{C}$.

For digesta passage rate, on day 7 of collection, $40 \mathrm{ml}$ of a liquid marker (Cr-EDTA) and $1 \mathrm{~g}$ of a solid marker $\left(\mathrm{Yb}_{2} \mathrm{O}_{3}\right)$ were mixed into the morning single meal. The meal was fed, and digesta were collected at 90, 180, 270, 360, 540 and 720 min after feed consumption ${ }^{(14)}$. The collected faeces, urine and digesta were pooled by pig observation and immediately frozen at $-20^{\circ} \mathrm{C}$. Faeces and digesta were homogenised, subsampled, freeze-dried and ground finely over a $0.5 \mathrm{~mm}$ screen in a centrifugal mill (model ZM1, Retsch; Brinkman Instruments, Rexdale, ON, Canada).

\section{Chemical analyses}

In vitro viscosity of diets and fibre sources was determined in a $0.5 \%$ solution using a rheometer (UDS 200; Paar Physica, Glenn, VA, USA) at a shear rate of $12.9 / \mathrm{s}$ and a temperature of $20^{\circ} \mathrm{C}^{(11)}$. In vitro gas production of diets was determined for $12 \mathrm{~h}$ by an in vitro gas production technique ${ }^{(12)}$. Diets, digesta and faeces were analysed in duplicate for DM, gross energy, starch, crude protein, diethyl ether extract, amino acids (AA) and total dietary fibre (soluble, insoluble and total). DM was analysed by drying at $135^{\circ} \mathrm{C}$ in an airflowtype oven for $2 \mathrm{~h}$ (method 930.15) ${ }^{(15)}$, gross energy using an adiabatic bomb calorimeter (model 5003; Ika-Werke GMBH \& Company KG, Staufen, Germany), crude protein by oxidation $(\mathrm{N} \times 6.25$, FP-428 $\mathrm{N}$ determinator; Leco Corporation, St Joseph, MI, USA), ash (method 9420.5) ${ }^{(15)}$ and diethyl ether extract using a Goldfish Extraction apparatus with diethyl ether as the solvent (method 920.39) ${ }^{(15)}$. The AA in digesta and feed were analysed by ion-exchange chromatography ${ }^{(16)}$. Total starch, total dietary fibre and mixed linked $\beta$-glucan were analysed using kits (Megazyme International Ireland Limited, Bray, Ireland) based on enzymatic analysis (methods 996.11, 2002.02, 985.29 and 995.16, respectively) ${ }^{(15)}$. $\mathrm{TiO}_{2}$ was analysed using a spectrophotometer (method $540.91)^{(15)}$. Fresh faecal and digesta samples were analysed for DM (method 930.15) ${ }^{(15)}$ and SCFA by GC with 4-methyl valeric acid as the internal standard ${ }^{(16)}$. Digesta samples were analysed for $\mathrm{pH}$ (Accumet Basic AB15; Fischer Scientific, Fairlawn, NJ, USA). Digesta viscosity was measured using a DV-I Viscometer with a cylindrical sample chamber and a SC4-18 spindle at 100, 50, 20, 10 and $5 \mathrm{rpm}$ (Brookfield, Middleboro, MA, USA). Digesta samples were incubated at $80^{\circ} \mathrm{C}$

Table 2. Analysed chemical composition and functional properties of the experimental diets containing four fibre sources (as-fed basis)

\begin{tabular}{|c|c|c|c|c|}
\hline \multirow[b]{2}{*}{ Items } & \multicolumn{2}{|c|}{ Low-fermentable } & \multicolumn{2}{|c|}{ High-fermentable } \\
\hline & $\begin{array}{l}\text { Low-viscous } \\
\text { CEL }\end{array}$ & $\begin{array}{l}\text { High-viscous } \\
\text { CMC }\end{array}$ & $\begin{array}{c}\text { Low-viscous } \\
\text { LBG }\end{array}$ & $\begin{array}{c}\text { High-viscous } \\
\text { HBG }\end{array}$ \\
\hline \multicolumn{5}{|l|}{ Chemical composition ( $\mathrm{g} / \mathrm{kg}$ ) } \\
\hline Starch & 629 & 602 & 602 & 575 \\
\hline \multicolumn{5}{|l|}{ Total dietary fibre } \\
\hline Insoluble & 53.8 & $19 \cdot 4$ & $19 \cdot 6$ & $45 \cdot 3$ \\
\hline Soluble & 0.00 & $47 \cdot 1$ & $61 \cdot 0$ & 43.4 \\
\hline Total & 53.8 & 66.5 & 80.6 & 88.7 \\
\hline$\beta$-Glucan & $00 \cdot 0$ & $00 \cdot 0$ & $50 \cdot 9$ & $45 \cdot 9$ \\
\hline Crude protein & 148 & 147 & 162 & 156 \\
\hline Diethyl ether extract & 4.0 & 2.6 & $6 \cdot 8$ & 6.4 \\
\hline Ash & 44.7 & $52 \cdot 6$ & $46 \cdot 4$ & 49.7 \\
\hline \multicolumn{5}{|l|}{ Indispensable amino acids } \\
\hline Arg & 3.5 & 3.5 & $4 \cdot 1$ & 3.8 \\
\hline His & $4 \cdot 1$ & 3.8 & 4.2 & 4.3 \\
\hline Ile & 8.6 & 8.5 & $9 \cdot 0$ & 8.9 \\
\hline Leu & 14.0 & 14.0 & $14 \cdot 8$ & 14.5 \\
\hline Lys & 11.5 & 11.5 & 11.9 & 11.7 \\
\hline Met & 2.5 & 2.4 & $2 \cdot 7$ & 2.5 \\
\hline Phe & 7.5 & 7.4 & $8 \cdot 0$ & 7.8 \\
\hline Thr & $5 \cdot 5$ & $5 \cdot 0$ & $6 \cdot 0$ & $5 \cdot 7$ \\
\hline Val & $10 \cdot 0$ & $9 \cdot 9$ & $10 \cdot 6$ & $10 \cdot 4$ \\
\hline \multicolumn{5}{|l|}{ Dispensable amino acids } \\
\hline Ala & $4 \cdot 6$ & 4.6 & $5 \cdot 2$ & $5 \cdot 1$ \\
\hline Asp & $10 \cdot 4$ & $10 \cdot 2$ & 11.3 & $12 \cdot 0$ \\
\hline Glu & 32.9 & 32.5 & 35.2 & 33.7 \\
\hline Gly & 3.1 & 3.1 & 4.3 & 3.7 \\
\hline Ser & 5.4 & 5.4 & $6 \cdot 1$ & $5 \cdot 6$ \\
\hline Tyr & 5.0 & 4.8 & $5 \cdot 3$ & $5 \cdot 3$ \\
\hline Gross energy (MJ/kg) & $15 \cdot 9$ & $15 \cdot 9$ & $16 \cdot 4$ & $16 \cdot 4$ \\
\hline In vitro viscosity $(\mathrm{mPa} \times \mathrm{s}(\mathrm{log}))^{*}$ & 0.40 & $3 \cdot 29$ & 1.69 & 3.54 \\
\hline Cumulative gas production $(\mathrm{ml} / \mathrm{g})$ & 36 & 19 & 187 & 167 \\
\hline
\end{tabular}

CEL, low-fermentable, low-viscous cellulose; CMC, low-fermentable, high-viscous carboxymethylcellulose; HBG, highfermentable, high-viscous oat $\beta$-glucan; LBG, high-fermentable, low-viscous oat $\beta$-glucan.

* In vitro viscosity of the four test ingredients was as follows: CEL, $0.49 \mathrm{mPa} \times \mathrm{s}$ (log); CMC, $2.46 \mathrm{mPa} \times \mathrm{s}$ (log); LBG, $1.38 \mathrm{mPa} \times \mathrm{s}(\mathrm{log}) ; \mathrm{HBG}, 2.32 \mathrm{mPa} \times \mathrm{s}(\mathrm{log})$. 
for $10 \mathrm{~min}$, cooled to $37^{\circ} \mathrm{C}$ and centrifuged at $3000 \mathrm{rpm}$ for $10 \mathrm{~min}$, and, subsequently, viscosity of the supernatant was measured. Viscosity values were converted to a $\log$ scale to reach a normal distribution. Cr-EDTA and $\mathrm{Yb}_{2} \mathrm{O}_{3}$ were analysed using an atomic absorption spectrometer (Varian SpectAA 240 FS; Agilent Technologies Canada Inc., Mississauga, ON, Canada) by a standard procedure ${ }^{(17)}$. Urinary $\mathrm{N}$ was analysed using the Kjeldahl method (method 968.06) ${ }^{(15)}$.

\section{Calculations}

The apparent ileal digestibility (AID) and apparent total tract digestibility (ATTD) of DM, crude protein, AA, ash, starch and energy were calculated using the $\mathrm{TiO}_{2}$ concentration of feed, digesta and faeces. Post-ileal DM digestibility was calculated as the difference between the ATTD and AID of DM. Digesta passage rate was calculated from the linear relationship following the first-order kinetics as described by the equation $\log Y=a-b X$, where $Y$ is the $\log$ of $\mathrm{Yb}_{2} \mathrm{O}_{3}$ concentration (mg $\left.\mathrm{Yb}_{2} \mathrm{O}_{3} / \mathrm{kg} \mathrm{DM}\right)$ and $X$ is the time (h), and thus the slope $(b)$ of the line is the rate constant that describes the digesta passage rate ${ }^{(18)}$. The marker excretion per hour was calculated using the equation ${ }^{(19)}$ :

$$
\% / \mathrm{h}=\left(1-\mathrm{e}^{b}\right) \times 100
$$

\section{Statistical analyses}

To compare differences among diets, data were subjected to ANOVA using the mixed procedure (SAS Institute Inc., Cary, NC, USA). The fixed effect of the diet $(n$ 4) and the random effect of the experimental period ( $n$ 4) and pigs $(n$ 8) were included in the main model. The pig was used as the experimental unit, and values are reported as least-square means. Specific effects of viscosity and fermentability and their interaction were analysed using contrast statements. If viscosity and fermentability interacted $(P<0 \cdot 10)$, means were separated using the probability of difference. Differences were considered significant if $P<0.05$ and were described as tendencies if $0.05 \leq P<0 \cdot 10$. Principal component (PC) analysis was performed using multivariate analysis (JMP software, version 8.0.1; SAS Institute Inc.), and the loading plot was used to determine correlations among individual variables of the first two eigenvalues (i.e. PC 1 and 2). The relationship between the AID of energy, crude protein and ash with post-ileal DM digestibility (fermentability) and viscosity was analysed using weighted linear and non-linear regression analysis (PROC REG; SAS Institute Inc.), with predicted values of the dependent variable adjusted for period and pig effects ${ }^{(20)}$.

\section{Results}

\section{Pigs and diets}

All pigs remained healthy throughout the experiment. The starch content differed slightly among diets (Table 2). Total dietary fibre content was mostly insoluble for the CEL diet and mostly soluble for the CMC and LBG diets. In contrast, the HBG diet contained equal insoluble and soluble total dietary fibre. The crude protein and AA content was higher in the LBG and HBG diets, because the two oat $\beta$-glucan concentrates contained some crude protein. Similarly, the gross energy content was higher in the LBG and HBG diets, which could be related to the fat impurities in the $\beta$-glucan concentrates. Diets met the minimum requirements of nutrients for pigs of that body-weight group.

\section{Average daily gain, digesta characteristics and nitrogen balance}

Viscosity and fermentability interacted (Table 3; $P<0 \cdot 001$ ) to change the average daily gain (ADG) of pigs; specifically, pigs fed the CMC diet had a 38\% lower $(P<0.05)$ ADG than pigs fed the other three fibre sources. Viscosity and fermentability did not affect the $\mathrm{pH}$ of ileal digesta. Viscosity and fermentability interacted to change (Table 3; $P<0$.001) digesta

Table 3. Average daily gain (ADG), physio-chemical characteristics of digesta and nitrogen balance of pigs fed the experimental diets containing four fibre sources

(Mean values with their standard errors, $n 8$ )

\begin{tabular}{|c|c|c|c|c|c|c|c|c|}
\hline & \multicolumn{2}{|c|}{ Low-fermentable } & \multicolumn{2}{|c|}{ High-fermentable } & \multirow[b]{3}{*}{ SEM } & \multirow{2}{*}{\multicolumn{3}{|c|}{$P$}} \\
\hline & Low-viscous & High-viscous & Low-viscous & High-viscous & & & & \\
\hline & CEL & $\mathrm{CMC}$ & LBG & $\mathrm{HBG}$ & & $V$ & $F$ & $V \times F$ \\
\hline \multicolumn{9}{|l|}{ Items } \\
\hline ADG $(g / d)$ & $540^{\mathrm{a}}$ & $330^{\mathrm{b}}$ & $530^{\mathrm{a}}$ & $570^{\mathrm{a}}$ & 50 & 0.006 & $<0.001$ & $<0.001$ \\
\hline $\mathrm{pH}$ & 4.7 & $5 \cdot 0$ & $5 \cdot 0$ & $5 \cdot 0$ & 0.2 & 0.335 & 0.456 & 0.449 \\
\hline Digesta viscosity $(\mathrm{mPa} \times \mathrm{s}(\mathrm{log}))$ & $2 \cdot 5^{\mathrm{c}}$ & $4 \cdot 1^{a}$ & $3 \cdot 2^{b}$ & $3 \cdot 3^{b}$ & 0.2 & $<0.001$ & $<0.001$ & $<0.001$ \\
\hline Fresh digesta (\% DM) & $17 \cdot 2^{\mathrm{a}}$ & $5 \cdot 5^{\mathrm{c}}$ & $8 \cdot 6^{\mathrm{b}}$ & $9 \cdot 0^{\mathrm{b}}$ & 0.9 & $<0.001$ & 0.019 & $<0.001$ \\
\hline Fresh faeces (\% DM) & $51 \cdot 3^{a}$ & $25 \cdot 9^{b}$ & $49 \cdot 9^{a}$ & $55 \cdot 4^{a}$ & $4 \cdot 7$ & $<0.001$ & $<0.001$ & $<0.001$ \\
\hline Total N intake $(\mathrm{g} / \mathrm{d})$ & $46 \cdot 8$ & $47 \cdot 7$ & $46 \cdot 1$ & $47 \cdot 5$ & $8 \cdot 1$ & 0.089 & 0.501 & 0.677 \\
\hline Faecal N loss (g/d) & $7 \cdot 6^{\mathrm{a}}$ & $5 \cdot 2^{b}$ & $6 \cdot 9^{\mathrm{a}, \mathrm{b}}$ & $8 \cdot 0^{\mathrm{a}}$ & $1 \cdot 7$ & 0.391 & 0.159 & 0.029 \\
\hline Urinary $N$ loss $(\mathrm{g} / \mathrm{d})$ & $9 \cdot 5$ & $12 \cdot 0$ & $10 \cdot 5$ & $10 \cdot 5$ & $1 \cdot 7$ & 0.218 & 0.792 & 0.240 \\
\hline$N$ retention $(g / d)$ & $30 \cdot 4$ & $31 \cdot 1$ & $28 \cdot 8$ & $29 \cdot 3$ & $5 \cdot 6$ & 0.633 & 0.223 & 0.943 \\
\hline Faecal:urinary $\mathrm{N}$ ratio & $0 \cdot 7^{a, b}$ & $0.5^{\mathrm{b}}$ & $0.6^{a, b}$ & $0 \cdot 8^{a}$ & 0.1 & 0.510 & 0.769 & 0.094 \\
\hline
\end{tabular}

CEL, low-fermentable, low-viscous cellulose; CMC, low-fermentable, high-viscous carboxymethylcellulose; HBG, high-fermentable, high-viscous oat $\beta$-glucan; LBG, high-

fermentable, low-viscous oat $\beta$-glucan; $V$, viscosity; $F$, fermentability.

${ }^{\mathrm{a}, \mathrm{b}, \mathrm{c}}$ Mean values within a row with unlike superscript letters were significantly different $(P<0.05)$. 
Table 4. Digesta passage rate of pigs fed the experimental diets containing four fibre sources

(Mean values with their standard errors, $n 8$ )

\begin{tabular}{|c|c|c|c|c|c|c|c|c|}
\hline \multirow[b]{2}{*}{ Items } & \multicolumn{2}{|c|}{ Low-fermentable } & \multicolumn{2}{|c|}{ High-fermentable } & \multirow[b]{2}{*}{ SEM } & \\
\hline & $\begin{array}{l}\text { Low-viscous } \\
\text { CEL }\end{array}$ & $\begin{array}{c}\text { High-viscous } \\
\text { CMC }\end{array}$ & $\begin{array}{l}\text { Low-viscous } \\
\text { LBG }\end{array}$ & $\begin{array}{c}\text { High-viscous } \\
\text { HBG }\end{array}$ & & $V$ & $F$ & $V \times F$ \\
\hline Digesta passage rate* & $0.30^{\mathrm{a}}$ & $0 \cdot 10^{b}$ & $0.29^{a}$ & $0.29^{a}$ & 0.07 & 0.124 & 0.010 & 0.095 \\
\hline Marker excretion $(\% / \mathrm{h}) \dagger$ & $21.0^{\mathrm{a}}$ & $7.9^{b}$ & $22 \cdot 9^{\mathrm{a}}$ & $25 \cdot 5^{\mathrm{a}}$ & 4.7 & 0.001 & 0.003 & 0.050 \\
\hline
\end{tabular}

CEL, low-fermentable, low-viscous cellulose; CMC, low-fermentable, high-viscous carboxymethylcellulose; HBG, high-fermentable, high-viscous oat $\beta$-glucan; LBG, high-fermentable, low-viscous oat $\beta$-glucan; $V$, viscosity; $F$, fermentability.

${ }^{\mathrm{a}, \mathrm{b}}$ Mean values within a row with unlike superscript letters were significantly different $(P<0.05)$.

${ }^{*}$ Calculated from the linear relationship following the first-order kinetics as described by the equation log $Y=a-b X$, where $Y$ is the log of $\mathrm{Yb}_{2} \mathrm{O}_{3}$ concentration

$\left(\mathrm{mg} \mathrm{Yb} \mathrm{O}_{3} / \mathrm{kg} \mathrm{DM}\right)$ and $X$ is the time (h), and thus the slope $(b)$ of the line is the rate constant.

$\dagger$ Calculated as $\left(1-\mathrm{e}^{b}\right) \times 100$.

viscosity (including its liquid fraction; data not shown) and DM content of digesta and faeces. Pigs fed the CMC diet had the highest $(P<0.05)$ digesta viscosity followed by the HBG and LBG diets, whereas pigs fed the CEL diet had the lowest $(P<0.05)$ digesta viscosity. The DM content of fresh digesta was highest $(P<0.05)$ for pigs fed the CEL diet, followed by the LBG and HBG diets, and was lowest $(P<0.05)$ for pigs fed the CMC diet. The DM content of fresh faeces was half $(P<0.05)$ for pigs fed the CMC diet than that for pigs fed the other three fibre sources.

Total $\mathrm{N}$ intake tended to be higher (Table 3; $P<0 \cdot 10$ ) after feeding high- than low-viscous fibre sources. Viscosity and fermentability interacted $(P<0.05)$ to affect faecal $\mathrm{N}$ loss; specifically, pigs fed the CMC diet had lower $(P<0.05)$ faecal $\mathrm{N}$ than those fed the CEL and HBG diets. Viscosity and fermentability did not affect urinary $\mathrm{N}$ loss and retention. Viscosity and fermentability tended to interact $(P<0 \cdot 10)$ to affect the faecal:urinary $\mathrm{N}$ ratio. Pigs fed the CMC diet had a lower faecal:urinary $\mathrm{N}$ ratio $(P<0.05)$ than those fed the HBG diet.

\section{Digesta kinetics}

Viscosity and fermentability tended to interact (Table 4; $P<0 \cdot 10)$ to affect digesta passage rate. The regression equations obtained for digesta passage rate had an $R^{2}$ value of $0.80,0.73,0.73$ and 0.77 for the CEL, CMC, LBG and HBG diets, respectively. The feeding of the $\mathrm{CMC}$ diet reduced $(P<0.05)$ digesta passage rate by $66 \%$ compared with that of the other three fibre sources (Table 4 ).

Table 5. Apparent ileal digestibility (AID) and total tract digestibility (ATTD) of nutrients in pigs fed the experimental diets containing four fibre sources (Mean values with their standard errors, $n 8$ )

\begin{tabular}{|c|c|c|c|c|c|c|c|c|}
\hline \multirow[b]{3}{*}{ Items } & \multicolumn{2}{|c|}{ Low-fermentable } & \multicolumn{2}{|c|}{ High-fermentable } & \multirow[b]{3}{*}{ SEM } & \multirow{2}{*}{\multicolumn{3}{|c|}{$P$}} \\
\hline & Low-viscous & High-viscous & Low-viscous & High-viscous & & & & \\
\hline & CEL & CMC & LBG & HBG & & $V$ & $F$ & $V \times F$ \\
\hline \multicolumn{9}{|l|}{ AID (\%) } \\
\hline Ash & $-41 \cdot 7^{\mathrm{c}}$ & $34.0^{\mathrm{a}}$ & $0.9^{\mathrm{b}}$ & $-26 \cdot 0^{c}$ & 8.0 & 0.003 & 0.236 & $<0.001$ \\
\hline Crude protein & $72 \cdot 8^{\mathrm{C}}$ & $85 \cdot 6^{\mathrm{a}}$ & $77 \cdot 7^{\mathrm{b}}$ & $72 \cdot 8^{\mathrm{C}}$ & 1.8 & 0.012 & 0.012 & $<0.001$ \\
\hline DM & $69 \cdot 8^{c}$ & $86 \cdot 5^{\mathrm{a}}$ & $75 \cdot 9^{b}$ & $72 \cdot 6^{\mathrm{c}}$ & 1.3 & $<0.001$ & $<0.001$ & $<0.001$ \\
\hline Energy & $76 \cdot 1^{\mathrm{b}}$ & $89 \cdot 6^{\mathrm{a}}$ & $78 \cdot 0^{b}$ & $77 \cdot 5^{\mathrm{b}}$ & $1 \cdot 1$ & $<0.001$ & 0.002 & $<0.001$ \\
\hline Starch & 98.5 & $97 \cdot 7$ & $96 \cdot 1$ & $98 \cdot 6$ & 1.3 & 0.694 & 0.350 & $0 \cdot 189$ \\
\hline Digestible energy (MJ/kg) & $11 \cdot 7^{\mathrm{C}}$ & $14 \cdot 2^{\mathrm{a}}$ & $12 \cdot 9^{b}$ & $12 \cdot 5^{\mathrm{b}}$ & 0.4 & $<0.001$ & 0.749 & $<0.001$ \\
\hline \multicolumn{9}{|l|}{ ATTD (\%) } \\
\hline Ash & $-49 \cdot 3^{b}$ & $40 \cdot 2^{a}$ & $-26 \cdot 3^{b}$ & $-35 \cdot 6^{b}$ & $15 \cdot 9$ & $<0.001$ & 0.016 & $<0.001$ \\
\hline Crude protein & $85 \cdot 0^{a, b}$ & $88 \cdot 8^{a}$ & $86 \cdot 3^{a, b}$ & $83 \cdot 2^{b}$ & 1.5 & 0.814 & 0.142 & 0.025 \\
\hline DM & $83 \cdot 6^{\mathrm{b}}$ & $87.9^{\mathrm{a}}$ & $88 \cdot 2^{a}$ & $85 \cdot 4^{a, b}$ & 1.3 & 0.432 & 0.319 & 0.003 \\
\hline Energy & $89.6^{\mathrm{b}}$ & $90 \cdot 5^{a, b}$ & $92 \cdot 5^{\mathrm{a}}$ & $89.8^{\mathrm{b}}$ & 0.8 & 0.257 & 0.141 & 0.027 \\
\hline \multicolumn{9}{|c|}{ 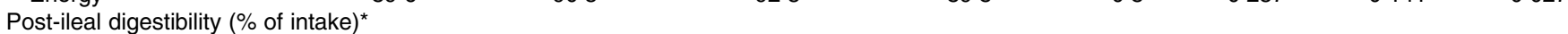 } \\
\hline Ash & $22 \cdot 3$ & 14.9 & $56 \cdot 8$ & $-9 \cdot 6$ & 8.8 & 0.038 & 0.233 & 0.128 \\
\hline Crude protein & $13 \cdot 0^{\mathrm{a}}$ & $4.0^{\mathrm{b}}$ & $8 \cdot 9^{\mathrm{a}, \mathrm{b}}$ & $10 \cdot 4^{\mathrm{a}, \mathrm{b}}$ & 2.6 & 0.171 & 0.680 & 0.065 \\
\hline DM & $13 \cdot 8^{\mathrm{a}}$ & $1.4^{\mathrm{b}}$ & $11 \cdot 4^{\mathrm{a}}$ & $12 \cdot 8^{\mathrm{a}}$ & 1.9 & 0.006 & 0.019 & $<0.001$ \\
\hline Energy & $13.5^{\mathrm{a}}$ & $0.8^{\mathrm{b}}$ & $11 \cdot 8^{\mathrm{a}}$ & $12 \cdot 3^{a}$ & 1.5 & $<0.001$ & 0.005 & 0.006 \\
\hline \multicolumn{9}{|c|}{ Post-ileal digestibility ( $\%$ of entering caecum) } \\
\hline Ash & -2.9 & $28 \cdot 0$ & $-32 \cdot 0$ & -8.8 & $14 \cdot 4$ & 0.032 & 0.011 & 0.732 \\
\hline Crude protein & $45 \cdot 7$ & 41.0 & $27 \cdot 9$ & 35.4 & 8.9 & 0.877 & 0.222 & 0.514 \\
\hline DM & $45 \cdot 4^{a}$ & $25 \cdot 5^{b}$ & $42 \cdot 6^{a}$ & $46 \cdot 0^{a}$ & $6 \cdot 1$ & 0.108 & 0.135 & 0.042 \\
\hline Energy & $56 \cdot 2^{\mathrm{a}}$ & $22 \cdot 8^{\mathrm{b}}$ & $55 \cdot 3^{\mathrm{a}}$ & $53 \cdot 6^{\mathrm{a}}$ & $5 \cdot 2$ & 0.005 & 0.012 & 0.009 \\
\hline
\end{tabular}

$\mathrm{CEL}$, low-fermentable, low-viscous cellulose; CMC, low-fermentable, high-viscous carboxymethylcellulose; HBG, high-fermentable, high-viscous oat $\beta$-glucan; LBG, highfermentable, low-viscous oat $\beta$-glucan; $V$, viscosity; $F$, fermentability.

a,b,c Mean values within a row with unlike superscript letters were significantly different $(P<0.05)$

* Calculated as the difference between ATTD and AID of nutrients. 
Apparent ileal, total tract and post-ileal nutrient digestibility

Viscosity and fermentability of fibre interacted to affect the AID of nutrients (Table $5 ; P<0.001$ ). The AID of crude protein, DM and ash were highest $(P<0.05)$ for pigs fed the CMC diet, intermediate for pigs fed the LBG diet and lowest $(P<0.05)$ for pigs fed the CEL and HBG diets. The AID of energy was $10-12 \%$ units higher $(P<0.05)$ in pigs fed the $\mathrm{CMC}$ diet than those fed the other three fibre sources, and digestible energy content followed a similar pattern.

Viscosity and fermentability of fibre interacted to affect (Table $5 ; P<0.001)$ the ATTD of nutrients. The ATTD of ash was higher $(P<0.05)$ for pigs fed the CMC diet than those fed the other three fibre sources. The ATTD of crude protein was highest $(P<0.05)$ for pigs fed the CMC diet and lowest $(P<0.05)$ for pigs fed the HBG diet. The ATTD of DM and energy were highest $(P<0 \cdot 05)$ for pigs fed the LBG diet and lowest $(P<0.05)$ for pigs fed the CEL diet.

Post-ileal ash digestibility, expressed as percentage of intake, was lower $(P<0.05)$ for pigs fed viscous fibre. Viscosity and fermentability tended to interact $(P<0 \cdot 1)$ to affect the post-ileal digestibility of crude protein and was highest $(P<0.05)$ for pigs fed the CEL diet and lowest $(P<0.05)$ for pigs fed the CMC diet. Similarly, viscosity and fermentability interacted $(P<0.05)$ to affect the post-ileal digestibility of $\mathrm{DM}$ and energy and was lower $(P<0.05)$ for pigs fed the CMC diet than those fed the other three fibre sources.

Post-ileal digestibility of ash as percentage of entering the caecum was affected by both viscosity $(P<0.05)$ and fermentability $(P<0 \cdot 05)$. Viscosity and fermentability interacted $(P<0.05)$ to affect the post-ileal digestibility of $\mathrm{DM}$ and energy and was lower $(P<0.05)$ for pigs fed the CMC diet than those fed the other three fibre sources (Table 5).

\section{Apparent ileal amino acid digestibility}

Viscosity and fermentability interacted (Table $6 ; P<0 \cdot 01$ ) to change the AID of all indispensable and dispensable AA; specifically, pigs fed the CMC diet had higher $(P<0.05)$ AID than those fed the other three fibre sources. Among the indispensable AA, pigs fed the CMC diet had the highest $(P<0.05)$ AID of isoleucine, lysine, methionine, threonine and valine, and pigs fed the CMC and LBG diets had the highest $(P<0.05)$ AID for arginine, leucine and phenylalanine. Pigs fed the HBG diet had the lowest $(P<0.05)$ AID of arginine, histidine, lysine and methionine, and pigs fed the CEL and HBG diets had the lowest $(P<0.05)$ AID for isoleucine, leucine, phenylalanine, threonine and valine.

\section{Digesta SCFA}

High-fermentable fibre sources reduced (Table 7; $P<0.05$ ) digesta acetate by $33 \%$ and tended to reduce $(P<0 \cdot 10)$ digesta total SCFA by $32 \%$. High-viscous non-starch polysaccharide sources tended to reduce $(P<0 \cdot 10)$ propionate by $50 \%$. Pigs fed the CEL diet had a higher $(P<0.05)$ butyrate, isobutyrate and isovalerate than those fed the other three fibre sources. High-viscous fibre sources increased $(P<0.05)$ digesta L-lactate and total lactate.

\section{Principal component analysis}

The PC analysis of AID of DM, digesta total SCFA, digesta viscosity and passage rate, and ADG is shown as a loading plot (Fig. 1). The plot revealed two clusters: a first cluster including digesta total SCFA, digesta passage rate and ADG that was affected by PC 1 , and the second cluster including AID of DM and digesta viscosity that was affected by PC 2. Variables

Table 6. Apparent ileal digestibility of amino acids (AA) in pigs fed the experimental diets containing four fibre sources (Mean values with their standard errors, $n 8$ )

\begin{tabular}{|c|c|c|c|c|c|c|c|c|}
\hline \multirow[b]{3}{*}{ Items } & \multicolumn{2}{|c|}{ Low-fermentable } & \multicolumn{2}{|c|}{ High-fermentable } & \multirow[b]{3}{*}{ SEM } & \multirow{2}{*}{\multicolumn{3}{|c|}{$P$}} \\
\hline & Low-viscous & High-viscous & Low-viscous & High-viscous & & & & \\
\hline & CEL & $\mathrm{CMC}$ & LBG & HBG & & $v$ & $F$ & $V \times F$ \\
\hline \multicolumn{9}{|c|}{ Indispensable AA (\%) } \\
\hline Arg & $78 \cdot 6^{\mathrm{b}}$ & $85 \cdot 2^{\mathrm{a}}$ & $80 \cdot 8^{a, b}$ & $67 \cdot 0^{\mathrm{c}}$ & $2 \cdot 3$ & 0.119 & 0.002 & $<0.001$ \\
\hline $\mathrm{His}$ & $90 \cdot 7^{\mathrm{a}, \mathrm{b}}$ & $93.4^{a}$ & $90 \cdot 1^{\mathrm{b}}$ & $87.0^{\mathrm{C}}$ & 1.0 & 0.871 & 0.002 & 0.008 \\
\hline Ile & $80 \cdot 2^{c}$ & $90 \cdot 5^{\mathrm{a}}$ & $85 \cdot 5^{\mathrm{b}}$ & $81.0^{\mathrm{C}}$ & $1 \cdot 7$ & 0.059 & 0.157 & $<0.001$ \\
\hline Leu & $88 \cdot 0^{\mathrm{b}, \mathrm{c}}$ & $92 \cdot 7^{\mathrm{a}}$ & $89 \cdot 4^{a, b}$ & $84.9^{\mathrm{C}}$ & 1.1 & 0.959 & 0.011 & $<0.001$ \\
\hline Lys & $87 \cdot 2^{\mathrm{b}}$ & $92 \cdot 0^{\mathrm{a}}$ & $87 \cdot 6^{\mathrm{b}}$ & $83 \cdot 6^{c}$ & $1 \cdot 1$ & 0.758 & 0.004 & 0.002 \\
\hline Met & $95 \cdot 0^{\mathrm{b}}$ & $98 \cdot 0^{\mathrm{a}}$ & $94.9^{b}$ & $91.8^{\mathrm{c}}$ & 0.6 & 0.927 & $<0.001$ & $<0.001$ \\
\hline Phe & $88 \cdot 7^{\mathrm{a}, \mathrm{b}}$ & $92 \cdot 5^{\mathrm{a}}$ & $89 \cdot 2^{\mathrm{a}}$ & $83.3^{\mathrm{b}}$ & 1.3 & 0.440 & 0.004 & 0.002 \\
\hline Thr & $74 \cdot 3^{\mathrm{b}, \mathrm{c}}$ & $85 \cdot 6^{\mathrm{a}}$ & $78 \cdot 6^{\mathrm{b}}$ & $71 \cdot 3^{\mathrm{C}}$ & 2.5 & 0.248 & 0.007 & $<0.001$ \\
\hline Val & $79 \cdot 6^{\mathrm{b}, \mathrm{c}}$ & $88.8^{\mathrm{a}}$ & $83 \cdot 1^{\mathrm{b}}$ & $77 \cdot 1^{\mathrm{c}}$ & 1.6 & 0.259 & 0.008 & $<0.001$ \\
\hline \multicolumn{9}{|c|}{ Dispensable AA (\%) } \\
\hline Ala & $71.5^{\mathrm{b}}$ & $82 \cdot 0^{\mathrm{a}}$ & $75 \cdot 3^{a, b}$ & $63.0^{\mathrm{C}}$ & 2.9 & 0.746 & 0.009 & $<0.001$ \\
\hline Asp & $77 \cdot 3^{b}$ & $85 \cdot 5^{\mathrm{a}}$ & $77 \cdot 0^{\mathrm{b}}$ & $69 \cdot 8^{\mathrm{c}}$ & $2 \cdot 3$ & 0.813 & $<0.001$ & $<0.001$ \\
\hline Glu & $85 \cdot 4^{b}$ & $92 \cdot 4^{\mathrm{a}}$ & $87 \cdot 6^{\mathrm{b}}$ & $86 \cdot 1^{\mathrm{b}}$ & 1.4 & 0.014 & 0.055 & $<0.001$ \\
\hline Gly & $50 \cdot 4^{\mathrm{a}}$ & $60 \cdot 5^{\mathrm{a}}$ & $52 \cdot 5^{\mathrm{a}}$ & $37.5^{\mathrm{b}}$ & 4.9 & 0.488 & 0.008 & 0.002 \\
\hline Ser & $67 \cdot 7^{\mathrm{b}}$ & $86 \cdot 6^{\mathrm{a}}$ & $75 \cdot 6^{\mathrm{c}}$ & $71.9^{b, c}$ & $3 \cdot 2$ & 0.002 & 0.125 & $<0.001$ \\
\hline Tyr & $92 \cdot 2^{\mathrm{a}}$ & $93.9^{a}$ & $91 \cdot 3^{a}$ & $85 \cdot 4^{b}$ & 1.0 & 0.065 & $<0.001$ & 0.002 \\
\hline
\end{tabular}

$\mathrm{CEL}$, low-fermentable, low-viscous cellulose; CMC, low-fermentable, high-viscous carboxymethylcellulose; HBG, high-fermentable, high-viscous oat $\beta$-glucan; LBG, high-fermentable, low-viscous oat $\beta$-glucan; $V$, viscosity; $F$, fermentability; ATTD, apparent total tract digestibility. ${ }^{a, b, c}$ Mean values within a row with unlike superscript letters were significantly different $(P<0.05)$. 
Table 7. Digesta SCFA concentrations and molar ratio in pigs fed the experimental diets containing four fibre sources

(Mean values with their standard errors, $n 8$ )

\begin{tabular}{|c|c|c|c|c|c|c|c|c|}
\hline \multirow[b]{3}{*}{ Items } & \multicolumn{2}{|c|}{ Low-fermentable } & \multicolumn{2}{|c|}{ High-fermentable } & \multirow[b]{3}{*}{ SEM } & \multirow{2}{*}{\multicolumn{3}{|c|}{$P$}} \\
\hline & Low-viscous & High-viscous & Low-viscous & High-viscous & & & & \\
\hline & CEL & $\mathrm{CMC}$ & LBG & HBG & & $V$ & $F$ & $V \times F$ \\
\hline \multicolumn{9}{|c|}{ Concentration ( $\mu \mathrm{mol} / \mathrm{g}$ fresh matter) } \\
\hline Acetate & $18 \cdot 8$ & $15 \cdot 5$ & $10 \cdot 1$ & $13 \cdot 0$ & $3 \cdot 3$ & 0.923 & 0.027 & 0.209 \\
\hline Propionate & $2 \cdot 8$ & 1.3 & $2 \cdot 4$ & 1.4 & 0.5 & 0.061 & 0.352 & 0.299 \\
\hline Butyrate & $1 \cdot 8^{\mathrm{a}}$ & $0.5^{\mathrm{b}}$ & $0 \cdot 7^{b}$ & $0.5^{\mathrm{b}}$ & 0.3 & 0.024 & 0.096 & 0.080 \\
\hline Isobutyrate & $0.22^{\mathrm{a}}$ & $0.07^{\mathrm{b}}$ & $0.01^{b}$ & $0.01^{\mathrm{b}}$ & 0.05 & 0.064 & 0.002 & 0.050 \\
\hline Valerate & $0 \cdot 12$ & 0.08 & 0.06 & 0.04 & 0.02 & 0.120 & 0.033 & 0.722 \\
\hline Isovalerate & $0.41^{\mathrm{a}}$ & $0 \cdot 14^{\mathrm{b}}$ & $0.04^{\mathrm{b}}$ & $0.04^{b}$ & 0.07 & 0.029 & $<0.001$ & 0.029 \\
\hline Caproate & $0 \cdot 17$ & $0 \cdot 10$ & 0.38 & 0.39 & 0.08 & 0.585 & 0.002 & 0.563 \\
\hline Total SCFA & $26 \cdot 1$ & $17 \cdot 8$ & $13 \cdot 8$ & $16 \cdot 1$ & 4.7 & 0.416 & 0.068 & 0.154 \\
\hline D-Lactate & $0 \cdot 19$ & $2 \cdot 47$ & 1.06 & 3.01 & 1.08 & 0.057 & 0.506 & 0.875 \\
\hline L-Lactate & 7.9 & $19 \cdot 2$ & $11 \cdot 6$ & $17 \cdot 5$ & 3.6 & 0.019 & 0.771 & 0.440 \\
\hline $\mathrm{D}+\mathrm{L}$-Lactate & $8 \cdot 1$ & $21 \cdot 6$ & $12 \cdot 7$ & $20 \cdot 5$ & $4 \cdot 3$ & 0.021 & 0.697 & 0.514 \\
\hline \multicolumn{9}{|l|}{ Molar ratio (\%) } \\
\hline Acetate & $75 \cdot 9$ & $87 \cdot 8$ & $75 \cdot 1$ & 82.5 & $2 \cdot 5$ & $<0.001$ & 0.404 & 0.226 \\
\hline Propionate & 13.9 & $7 \cdot 6$ & $16 \cdot 6$ & $9 \cdot 3$ & 1.9 & $<0.001$ & 0.492 & 0.861 \\
\hline Butyrate & $5 \cdot 6$ & $2 \cdot 3$ & 4.4 & $3 \cdot 2$ & 0.6 & 0.006 & 0.488 & 0.218 \\
\hline
\end{tabular}

CEL, low-fermentable, low-viscous cellulose; CMC, low-fermentable, high-viscous carboxymethylcellulose; HBG, high-fermentable, high-viscous oat $\beta$-glucan; LBG, high-fermentable, low-viscous oat $\beta$-glucan; $V$, viscosity; $F$, fermentability.

${ }_{a, b, c}$ Mean values within a row with unlike superscript letters were significantly different $(P<0.05)$.

within a cluster were positively correlated. The two clusters were correlated negatively, because the angle between the two clusters exceeded $90^{\circ}$. Thus, the AID of DM was related positively to ileal digesta viscosity, whereas digesta total SCFA were related positively to digesta passage rate.

\section{Relationship between fermentability and viscosity with nutrient digestibility}

Post-ileal DM digestibility was related strongly, inversely and curvilinearly $\left(R^{2} 0.85,0.72,0.73\right.$, respectively; Fig. 2; $P<0.001)$ to the AID of energy, crude protein and ash. Instead, digesta viscosity was not related strongly $\left(R^{2} 0 \cdot 45\right.$, $0.36,0.36$, respectively; Fig. $3 ; P<0.001)$ to the AID of energy, crude protein and ash.

\section{Discussion}

The effects of dietary fibre on nutrient digestibility are well known; however, a dearth of studies explains the role of the two functional properties of fibre, i.e. viscosity and fermentability, and their interactions on nutrient digestibility. Viscosity as related to dietary fibre refers to the ability to thicken or form gels when mixed with fluids resulting from physical entanglements among the fibre within the fluid ${ }^{(2)}$. Increased digesta viscosity after feeding soluble fibre such as guar gum, rye and pectin decreased nutrient digestibility in pigs $^{(1,7)}$. In contrast, very-high-viscous carboxymethylcellulose improved crude protein digestibility in weaned pigs ${ }^{(21)}$. The fibre is not digested by porcine enzymes but is instead fermented by the microbial community in the distal small and large intestine. The amount of viscosity may have an impact on the amount of fermentation, because non-viscous fibre may increase digesta passage rate and reduce small-intestinal digestibility, and thus partly shifts enzymatic digestion to microbial fermentation ${ }^{(1)}$. Similarly, an interaction of viscosity and fermentability affected most of the variables related to digestion and digesta characteristics.

The present study was designed to study the effects of functional properties of dietary fibre using semi-purified diets supplemented with concentrated fibre sources. The selected fibre sources were glucose polymers with $\beta$-linkages, and their functional properties were assessed using in vitro viscosity and gas production measurements. However, we acknowledge that factors other than these two properties, e.g. differences in chemical structure, use of naturally extracted (oat $\beta$-glucan and cellulose) $v$. chemically modified

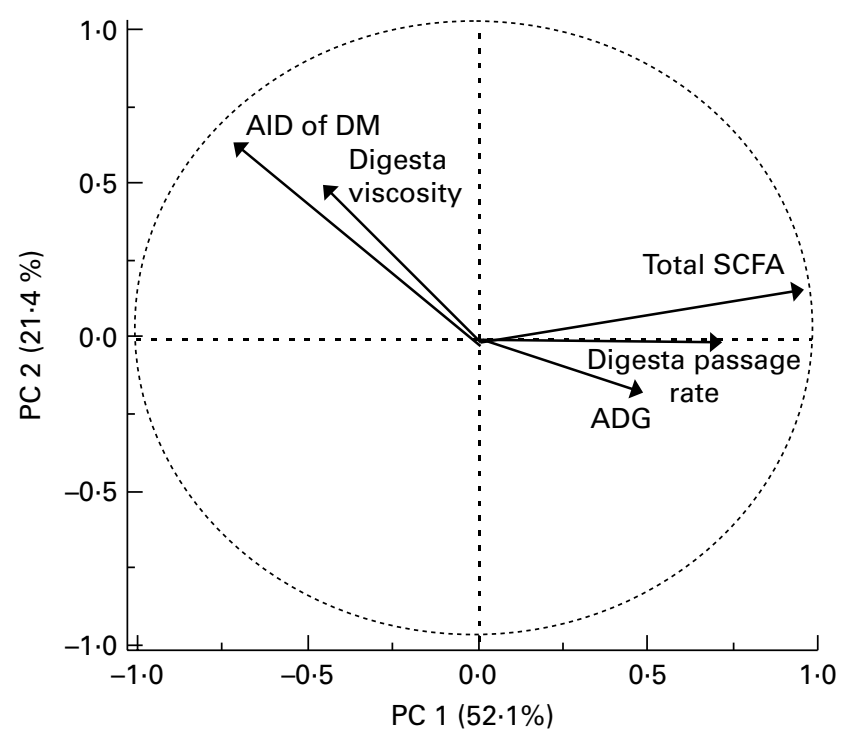

Fig. 1. Loading plot of principal component (PC) analysis showing correlations among apparent ileal digestibility (AID) of DM, total SCFA, digesta viscosity and digesta passage rate, and average daily gain (ADG) of the first two eigenvalues (PC 1 and PC 2). 

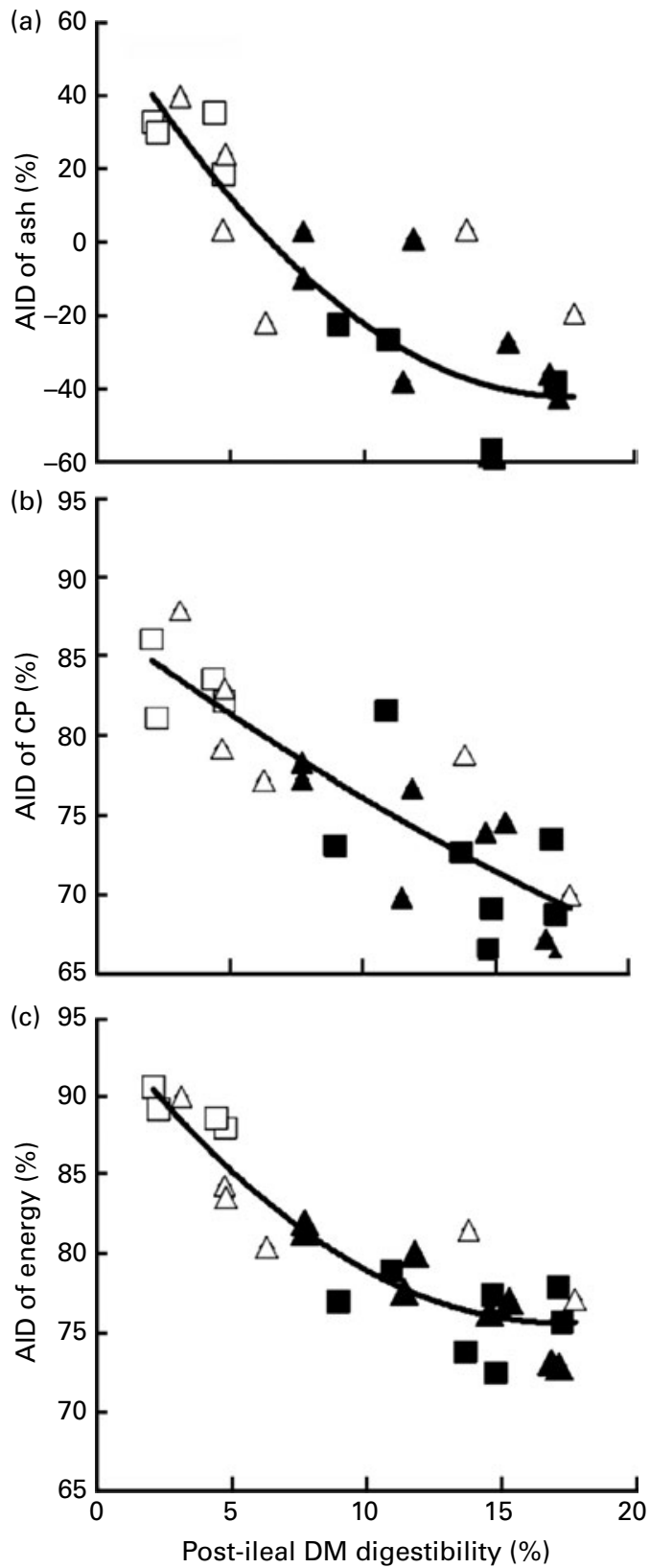

Fig. 2. Relationship between post-ileal DM digestibility and (a) apparent ileal digestibility (AID) of (a) ash $\left(R^{2} 0.73, P<0.001\right)$, (b) crude protein (CP, $R^{2}$ $0.72, P<0.001)$ and (c) energy $\left(R^{2} 0.85, P<0.001\right)$ of pigs fed the experimental diets containing either $5 \%$ cellulose $(\square)$, carboxymethylcellulose $(\square)$, low-viscous oat $\beta$-glucan $(\Delta)$ or high-viscous oat $\beta$-glucan $(\boldsymbol{\Lambda})$.

cellulose sources such as CMC, might have contributed to the physiological effects observed in the present study ${ }^{(22)}$.

In the present study, the interaction of viscosity and fermentability affected ADG and digesta characteristics. The ADG was lowest for pigs fed the CMC diet compared with pigs fed the other three fibre diets. The watery digesta and faeces for pigs fed the CMC diet indicated less water retention and the onset of diarrhoea, similar to the observation with weaned pigs fed a CMC diet or pearled barley ${ }^{(23-25)}$, and the watery digesta was related to high digesta viscosity. The high digesta viscosity by inclusion of CMC in diets slows digesta passage rate and thereby creates a favourable environment for the proliferation of microbial pathogens ${ }^{(26)}$. Indeed, in the present study, pigs fed the CMC diet had an increased prevalence of Escherichia coli virulence factors in digesta $^{(27)}$. In this context, CMC may bind with the intestinal mucus layer and change its composition to facilitate the binding of $E$. coli to the intestinal mucus ${ }^{(28)}$. Inclusion of CMC in broiler chick diets reduced $\mathrm{Na}$ and water retention that could further explain the diarrhoea caused by $\mathrm{CMC}^{(29)}$. Thus, the present study indicated a strong association between digesta viscosity and reduced body-weight gain.
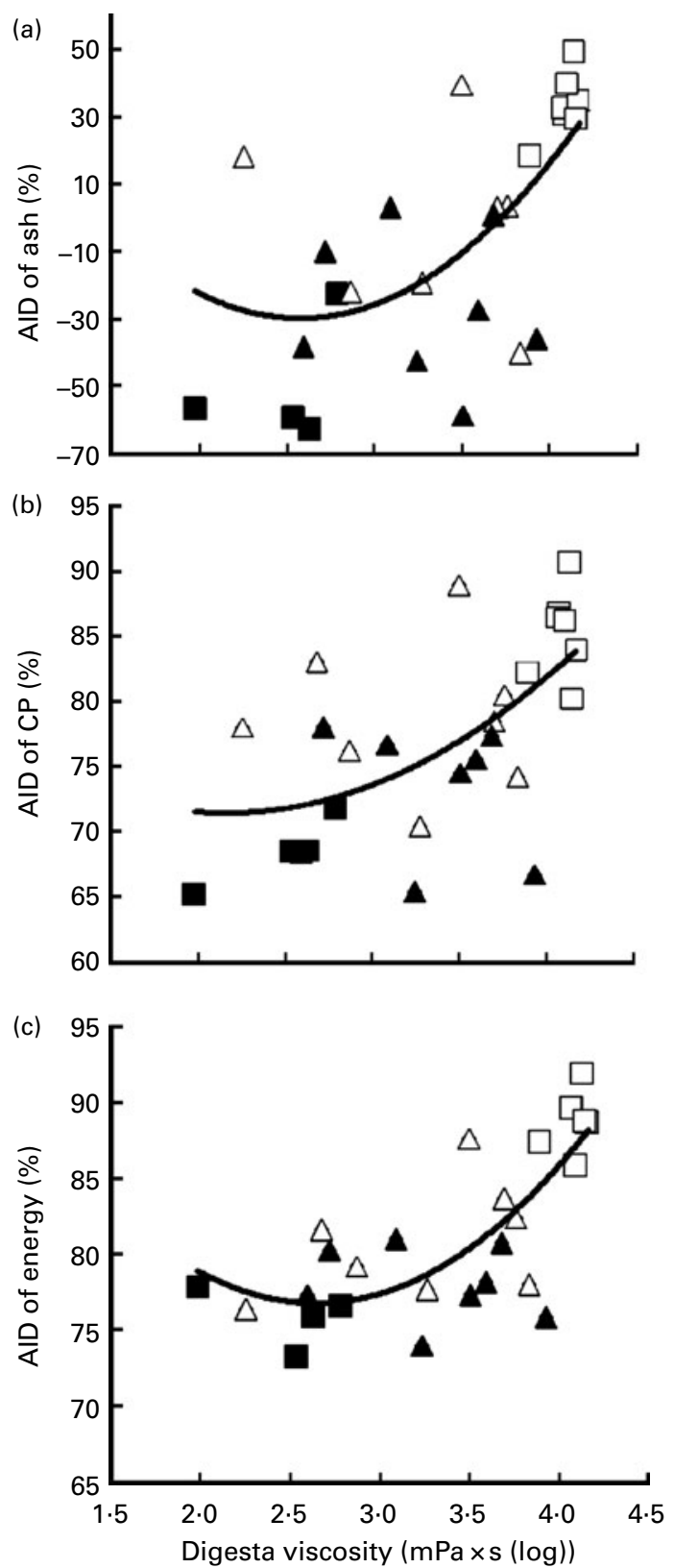

Fig. 3. Relationship between digesta viscosity of pigs with (a) apparent ileal digestibility (AID) of (a) ash $\left(R^{2} 0.36, P=0.005\right)$, (b) crude protein (CP, $R^{2}$ $0.36, P=0.004)$ and (c) energy $\left(R^{2} 0.45, P<0.001\right)$ of pigs fed the experimental diets containing either $5 \%$ cellulose $(\square)$, carboxymethylcellulose $(\square)$, low-viscous oat $\beta$-glucan $(\triangle)$ or high-viscous oat $\beta$-glucan $(\mathbf{\Delta})$. 
Viscosity and fermentability of fibre interacted to modify digesta viscosity. Dietary CMC caused high digesta viscosity in swine ${ }^{(30)}$ and poultry ${ }^{(31)}$, which was related to the high solubility of $\mathrm{CMC}^{(27)}$. The high in vivo viscosity matched perfectly with the high in vitro viscosity, and thus appeared to confirm the paradigm that a high-viscosity diet results in high digesta viscosity ${ }^{(2)}$. Indeed, pigs fed the HBG diet with high in vitro viscosity also had high digesta viscosity, similar to that observed in studies with rats ${ }^{(32)}$. However, in spite of low in vitro diet viscosity, pigs fed the LBG diet had the same digesta viscosity as pigs fed the HBG diet. The high in vivo viscosity for the LBG diet might be due to linkages of starch fragments to $\beta$-glucan ${ }^{(33)}$ or different patterns of degradation between $\beta$-glucan sources in the small intestine ${ }^{(34)}$. The exact location and mechanism in the gastrointestinal tract for the equalisation of digesta viscosity between LBG and HBG requires further analysis but points to in vitro viscosity not being entirely dependable to predict in vivo viscosity.

Changes in the physical properties of digesta, i.e. viscosity, affected digesta passage rate and thereby nutrient digestibility $^{(35)}$. Specifically, high-viscous CMC reduced digesta passage rate similar to pigs fed soluble fibre that increased digesta viscosity and decreased digesta passage rate ${ }^{(1,5)}$. When pigs were fed diets containing CMC, increased digesta viscosity can reduce passage rate by reducing the gastric emptying rate $^{(24)}$. Effects of soluble or insoluble fibre on digesta passage rate are not consistent among studies. For example, soluble fibre did not alter digesta passage rate in pigs ${ }^{(36,37)}$ as observed in the present study, where digesta viscosity of pigs fed diets containing HBG and LBG was not high enough to reduce the digesta passage rate that thus remained comparable with pigs fed the low-viscous CEL diet. Dietary fibre may increase the peristaltic action of the intestine ${ }^{(22)}$ or increase the digesta bulk ${ }^{(38)}$ that might compensate the effects of digesta viscosity on digesta passage rate. In the present study, PC analysis indicated that reduced digesta passage rate was positively correlated with nutrient digestibility, thereby confirming the paradigm that slow digesta passage rate leads to more time for enzymatic digestion, thereby improving digestibility ${ }^{(21)}$. This proposed mechanism increased AID of crude protein and AA in pigs fed highviscous CMC. In contrast to pigs fed the CMC diet, pigs fed the CEL diet as an insoluble fibre had a higher digesta passage rate and a lower mean retention time in the ileum ${ }^{(14)}$. Thus, the CEL diet decreased the contact time between digestive enzymes and substrates, thereby explaining the lower DM and crude protein digestibility in pigs fed the CEL diet ${ }^{(1)}$. In pigs fed the HBG and LBG diets, the higher digesta passage rate probably caused lower AID of crude protein and energy compared with pigs fed the CMC diet. Moreover, high digesta viscosity may increase endogenous $\mathrm{N}$ secretion that may also contribute to a reduced AID of crude protein as observed for pigs fed the HBG diet ${ }^{(39)}$. Finally, digesta viscosity might have caused changes in gut motility and mixing of digesta and thus lower nutrient digestibility ${ }^{(24)}$.

The results for ash digestibility were unique in the present study. The ATTD of ash was negative after feeding the fibre sources except for CMC, similar to recent findings in sows ${ }^{(7)}$. The negative digestibility could be due to endogenous secretion of minerals ${ }^{(40)}$ or due to increased mineral requirements for microbial activity ${ }^{(41)}$. The positive ATTD of ash values with high-viscous CMC could be due to the decreased digesta passage rate, which in turn increased digestion and absorption in the small intestine ${ }^{(42)}$. In contrast, the HBG and LBG diets increased fermentation, and thus more microbial mass and more secretion of minerals for microbial requirements $^{(41)}$. Finally, CEL as an insoluble dietary fibre may damage the mucosa by mechanical abrasion and thus inhibit transcellular carrier-mediated mineral absorption ${ }^{(43)}$.

Feeding fibre to pigs is a strategy to shift the excretion of $\mathrm{N}$ from urine to faeces ${ }^{(44)}$. Dietary fermentable fibre increases intestinal microbial populations that require $\mathrm{N}$ for their protein synthesis, and thereby reduces $\mathrm{N}$ absorption by the pig or stimulates a $\mathrm{N}$ flux from the pig into its intestine, thus effectively reducing the excretion of excess $\mathrm{N}$ in urine ${ }^{(45)}$. In the present study, fermentable fibre caused a trend to increase the ratio of faecal:urinary $\mathrm{N}$, indicating a shift of $\mathrm{N}$ from urine to faeces, similar to that observed in previous studies ${ }^{(46)}$, but with a major contribution of CMC to reduce faecal $\mathrm{N}$ loss. However, fermentable fibre did not cause a shift as strong in the present study, because highly digestible protein ingredients were fed and the supply of AA matched their requirements well so that less excess $\mathrm{N}$ was available to be shifted to $\mathrm{N}$ excretion in the faeces.

The presence of SCFA in digesta indicated that the intestinal microflora did start fermentation of purified fibre sources by the end of the ileum, similar to that observed in studies with grower pigs ${ }^{(47)}$ and sows ${ }^{(7)}$. The fermentation of these sources continued in the large intestine ${ }^{(27)}$. Post-ileal DM digestibility, an indicator of fermentation ${ }^{(48)}$, did not differ among pigs fed the CEL, LBG and HBG diets. The inverse relationship between post-ileal DM digestibility and AID of energy indicated that the DM not digested in the small intestine was fermented in the large intestine. The lower digesta passage rate in pigs fed the $\mathrm{CMC}$ diet reduced the flow of DM into the large intestine for fermentation. The PC analysis confirmed this proposed mechanism, because digesta SCFA were positively correlated with digesta passage rate and negatively with nutrient digestibility. Interestingly, the interaction of viscosity and fermentability affected digesta butyrate, which was higher in the digesta of pigs fed diets containing CEL. Higher digesta butyrate may be beneficial for the intestinal health, because butyrate is the preferred source of energy for colonocytes and prevents colon cancer ${ }^{(49)}$. Furthermore, increased digesta lactate in pigs fed the CMC and HBG diets supported that intestinal absorption and bacterial utilisation of lactate ${ }^{(50)}$ can be markedly impaired by higher digesta viscosity in the upper gastrointestinal tract ${ }^{(22)}$.

In conclusion, pigs fed a high-viscous CMC diet had the highest AID of nutrients, by slowing down the rate of digesta passage. In contrast, faster digesta passage reduced the AID of nutrients in pigs fed the CEL diet compared with pigs fed the CMC diet, thereby increased nutrient flow into the large intestine so that part of the nutrients that would normally be digested were instead fermented. Thus, negative effects of 
dietary fibre on digesta characteristics and nutrient digestibility are affected by interactions of viscosity and fermentability via digesta viscosity and digesta passage rate.

\section{Acknowledgements}

The present study was financially supported by Danisco Animal Nutrition, Provimi, Alberta Pulse Growers, and Agriculture and Food Council of Alberta. S. H. was supported by an Alberta Ingenuity PhD Student Scholarship. None of the authors had a conflict of interest. We thank Dr Rajesh Jha for providing data of cumulative gas production. S. H., B. U. M.-Z., T. V. and R. T. Z. designed the study; S. H., B. U. M.-Z. and R. T. Z. conducted the animal procedures and analysed the data; S. H. and R. T. Z. wrote the manuscript; R. T. Z. had the primary responsibility for the final content.

\section{References}

1. Owusu-Asiedu A, Patience JF, Laarveld B, et al. (2006) Effects of guar gum and cellulose on digesta passage rate, ileal microbial populations, energy and protein digestibility, and performance of grower pigs. J Anim Sci 84, 843-852.

2. Dikeman CL \& Fahey GC (2006) Viscosity as related to dietary fiber: a review. Crit Rev Food Sci Nutr 46, 649-663.

3. Graham H, Hesselman K \& Aman P (1986) The influence of wheat bran and sugar-beet pulp on the digestibility of dietary components in a cereal-based pig diet. J Nutr 116, 242-251.

4. Renteria-Flores JA, Johnston LJ, Shurson GC, et al. (2008) Effect of soluble and insoluble fiber on energy digestibility, nitrogen retention, and fiber digestibility of diets fed to gestating sows. J Anim Sci 86, 2568-2575.

5. Bach Knudsen KE \& Hansen I (1991) Gastrointestinal implications in pigs of wheat and oat fractions. 1. Digestibility and bulking properties of polysaccharides and other major constituents. Br J Nutr 65, 217-232.

6. Kirchgessner M, Muller HL \& Roth FX (1991) Digestibility, intestinal passage time and energy value of wheat bran in model studies in sows. Z Ernabrungswiss 30, 118-130.

7. Serena A, Jorgensen H \& Bach Knudsen KE (2008) Digestion of carbohydrates and utilization of energy in sows fed diets with contrasting levels and physicochemical properties of dietary fiber. J Anim Sci 86, 2208-2216.

8. Bach Knudsen KE, Jensen BB \& Hansen I (1993) Digestion of polysaccharides and other major components in the small and large intestine of pigs fed on diets consisting of oat fractions rich in $\beta$-D-glucan. Br J Nutr 70, 537-556.

9. Canadian Council on Animal Care (1993) Guide to the Care and Use of Experimental Animals, 2nd ed., vol. 1. Ottawa, ON: Canadian Council on Animal Care.

10. NRC (1998) Nutrient Requirements of Swine, 10th revised ed. Washington, DC: National Academy Press.

11. Ghotra BS, Vasanthan T \& Temelli F (2009) Rheological properties of aqueous blends of high purity barley beta-glucan with high purity commercial food gums. Food Chem 117, 417-425.

12. Jha R, Bindelle J, Rossnagel B, et al. (2011) In vitro evaluation of the fermentation characteristics of the carbohydrate fractions of hulless barley and other cereals in the gastrointestinal tract of pigs. Anim Feed Sci Technol 163, 185-193.

13. Van Kleef DJ, Deuring K \& Van Leeuwen P (1994) A new method of feces collection in the pig. Lab Anim 28, 78-79.
14. Wilfart A, Montagne L, Simmins H, et al. (2007) Digesta transit in different segments of the gastrointestinal tract of pigs as affected by insoluble fibre supplied by wheat bran. Br J Nutr 98, 54-62.

15. AOAC (2006) Official Methods of Analysis, 18th ed. Arlington, VA: Association of Official Analytical Chemists.

16. Htoo JK, Araiza BA, Sauer WC, et al. (2007) Effect of dietary protein content on ileal amino acid digestibility, growth performance, and formation of microbial metabolites in ileal and cecal digesta of early-weaned pigs. J Anim Sci 85, 3303-3312.

17. Siddons RC, Paradine J, Beever DE, et al. (1985) Ytterbium acetate as a particulate-phase digesta-flow marker. $\mathrm{Br} J$ Nutr 54, 509-519.

18. Potkins Z, Lawrence VTL \& Thomlinson JR (1991) Effects of structural and non-structural polysaccharides in the diet of the growing pig on gastric emptying rate and rate of passage of digesta to the terminal ileum and through the total gastrointestinal tract. Br J Nutr 65, 391-413.

19. Keys JE Jr \& DeBarthe JV (1974) Site and extent of carbohydrate, dry matter, energy and protein digestion and the rate of passage of grain diets in swine. J Anim Sci 39, 57-62.

20. St-Pierre NR (2001) Invited review: integrating quantitative findings from multiple studies using mixed model methodology. J Dairy Sci 84, 741-755.

21. Fledderus J, Bikker P \& Kluess JW (2007) Increasing diet viscosity using carboxymethylcellulose in weaned piglets stimulates protein digestibility. Livest Sci 109, 89-92.

22. Wenk C (2001) The role of dietary fibre in the digestive physiology of the pig. Anim Feed Sci Technol 90, 21-33.

23. McDonald DE, Pethick DW, Mullan BP, et al. (2001) Increasing viscosity of the intestinal contents alters small intestinal structure and intestinal growth, and stimulates proliferation of enterotoxigenic Escherichia coli in newly-weaned pigs. Br J Nutr 86, 487-498.

24. Montagne L, Pluske JR \& Hampson DJ (2003) A review of interactions between dietary fibre and the intestinal mucosa, and their consequences on digestive health in young non-ruminant animals. Anim Feed Sci Technol 108, 95-117.

25. Hopwood DE, Pethick DW, Pluske JR, et al. (2004) Addition of pearl barley to a rice-based diet for newly weaned piglets increases the viscosity of the intestinal contents, reduces starch digestibility and exacerbates post-weaning colibacillosis. Br J Nutr 92, 419-427.

26. van der Klis JD, van Voorst A \& van Cruyningen C (1993) Effect of a soluble polysaccharide (carboxy methyl cellulose) on the physico-chemical conditions in the gastrointestinal tract of broilers. Br Poult Sci 34, 971-983.

27. Metzler-Zebeli BU, Hooda S, Pieper R, et al. (2010) Non-starch polysaccharides modulate bacterial microbiota, pathways for butyrate production, and abundance of pathogenic Escherichia coli in the gastrointestinal tract of pigs. Appl Environ Microbiol 76, 3692-3701.

28. Rossi S, Bonferoni MC, Ferrari F, et al. (1996) Characterization of mucin interaction with three viscosity grades of sodium carboxymethylcellulose. Comparison between rheological and tensile testing. Eur J Pharma Sci 4, 189-196.

29. Johnson IT \& Gee JM (1986) Gastrointestinal adaptation in response to soluble non-available polysaccharides in the rat. Br J Nutr 55, 497-505.

30. Piel C, Montagne L, Seve B, et al. (2005) Increasing digesta viscosity using carboxymethylcellulose in weaned piglets stimulates ileal goblet cell numbers and maturation. $J$ Nutr 135, 86-91. 
31. Waldenstedt L, Elwinger K, Lunden A, et al. (2000) Intestinal digesta viscosity decreases during coccidial infection in broilers. Br Poult Sci 41, 459-464.

32. Gallaher DD, Wood KJ, Gallaher CM, et al. (1999) Intestinal contents supernatant viscosity of rats fed oat based muffins and cereal products. Cereal Chem 76, 21-24.

33. Faraj A, Vasanthan $T$ \& Hoover R (2006) The influence of alpha-amylase-hydrolysed barley starch fractions on the viscosity of low and high purity barley beta-glucan concentrates. Food Chem 96, 56-65.

34. Sundberg B, Wood P, Lia A, et al. (1996) Mixed-linked betaglucan from breads of different cereals is partly degraded in the human ileostomy model. Am J Clin Nutr 64, 878-885.

35. Lantle RG \& Janssen PW (2010) Manipulating digestion with foods designed to change the physical characteristics of digesta. Crit Rev Food Sci Nutr 50, 130-145.

36. Latymer EA, Low AG, Fadden K, et al. (1990) Measurement of transit time of digesta through sections of gastrointestinal tract of pigs fed with diets containing various sources of dietary fibre (non-starch polysaccharides). Arch Tierernabr $\mathbf{4 0}$ 667-680.

37. Van Leeuwen P, van Gelder AH, de Leeuw JA, et al. (2006) An animal model to study digesta passage rate in different compartments of the gastrointestinal tract (GIT) as affected by dietary composition. Curr Nutr Food Sci 2, 97-105.

38. Stanogias G \& Pearce GR (1985) The digestion of fibre by pigs. 1. The effects of amount and type of fibre on apparent digestibility, nitrogen balance and rate of passage. BrJ Nutr 53, 513-530.

39. Fan MC \& Sauer WC (2002) Determination of true ileal amino acid digestibility and endogenous amino acid outputs associated with barley samples for growing-finishing pigs by the regression analysis technique. J Anim Sci 80, 1593-1605.

40. Dierick NA, Vervaeke IJ, Demeyer DI, et al. (1989) Approach to the energetic importance of fibre digestion in pigs I. Importance of fermentation in the overall energy supply. Anim Feed Sci Technol 23, 141-167.
41. Metzler BU, Vahjen W, Baumgärtel T, et al. (2009) Changes in bacterial populations in the ileum of pigs fed lowphosphorus diets supplemented with different sources of fermentable carbohydrates. Anim Feed Sci Technol 148, 70-91.

42. Powell JJ, Whitehead MW, Lee S, et al. (1994) Mechanisms of gastrointestinal absorption: dietary minerals and the influence of beverage ingestion. Food Chem 51, 381-388.

43. Oku T, Konishi F \& Hosoya N (1982) Mechanism of inhibitory effect of carbohydrate on intestinal calcium absorption. J Nutr 112, 410-415.

44. Kreuzer M, Machmuller A, Gerdemann MM, et al. (1998) Reduction of gaseous nitrogen loss from pig manure using feeds rich in easily-fermentable non-starch polysaccharides. Anim Feed Sci Technol 73, 1-19.

45. Canh TT, Sutton AL, Aarnink AJA, et al. (1998) Dietary carbohydrates alter the fecal composition and $\mathrm{pH}$ and the ammonia emission from slurry of growing pigs. J Anim Sci 76, $1887-1895$

46. Zervas S \& Zijlstra RT (2002) Effects of dietary protein and oathull fiber on nitrogen excretion patterns and postprandial plasma urea profiles in grower pigs. J Anim Sci 80, $3238-3246$

47. Bach Knudsen KE, Jensen BB, Andersen JO, et al. (1991) Gastrointestinal implications in pigs of wheat and oat fractions. 2. Microbial activity in the gastrointestinal tract. $\mathrm{Br} \mathrm{J}$ Nutr 65, 233-248.

48. Baumgartel T, Metzler BU, Mosenthin R, et al. (2008) Precaecal and postileal metabolism of $\mathrm{P}, \mathrm{Ca}$ and $\mathrm{N}$ in pigs as affected by different carbohydrate sources fed at low level of P intake. Arch Anim Nutr 62, 169-181.

49. Wong JM, de Souza R, Kendall CW, et al. (2006) Colonic health: fermentation and short chain fatty acids. J Clin Gastroenterol 40, 235-243.

50. Louis P, Scott KP, Duncan SH, et al. (2007) Understanding the effects of diet on bacterial metabolism in the large intestine. J Appl Microbiol 102, 1197-1208. 